\title{
TALES OF A FLOW STAYED BY NOTHING: MENSTRUATION IN IMMIGRATION DETENTION
}

\section{KIT JOHNSON*}

When Fauziya Kassindja landed at New York's JFK airport in 1994, she was seventeen, seeking asylum, and fleeing the brutal practice of female genital mutilation. ${ }^{1}$ She was also menstruating. ${ }^{2}$ Hours after her arrival, Fauziya was strip searched, forced to stand before a female officer "completely naked, soiled pad exposed, shamed beyond words." ${ }^{3}$ She was then transferred to an off-site detention facility where she was stripsearched again. When Fauziya asked where she should place her soiled pad, the female guard responded: "I don't know. Why don't you eat it?" ${ }^{4}$ When Fauziya asked for a new pad, she was told she could ask for one the next morning. ${ }^{5}$ She was given absolutely nothing to stay her flow - not even toilet paper or paper towels. This was the beginning of Fauziya's experience with immigration detention. She would remain there for sixteen months. ${ }^{6}$

Immigration detention is an unusual beast with familiar outlines. Let's start with the unfamiliar. The process by which the United States determines whether an individual

\footnotetext{
${ }^{*}$ Professor at the University of Oklahoma College of Law. I am thankful to the Columbia Journal of Gender and Law for including me in their Spring 2021 symposium Are You There, Law? It's Me, Menstruation. The symposium's title comes from Judy Blume's 1970 novel Are You There, God? It's Me, Margaret, a remarkable book that talks frankly about menstruation. The title of this Essay draws inspiration from Blume's 1972 novel Tales of a Fourth Grade Nothing. I thank as well Professor Eric E. Johnson for his thoughtful feedback and insights on this work. (c) 2020 Kit Johnson. Konomark-Most rights sharable. See konomark.org.
}

${ }^{1}$ Fauziya Kassindja \& Layli Miller Bashir, Do They Hear You When You Cry (1998). Female genital mutilation (FGM) is a cultural practice involving the permanent removal of the clitoris of a girl or young woman and, in some cases, parts of their labia minor or labia majora and even, perhaps, suturing closed much of the labia majora. See Layli Miller Bashir, Female Genital Mutilation in the United States: An Examination of Criminal and Asylum Law, 4 AM. U. J. GENDER \& L. 415, 416-17, 419-21 (1996).

${ }^{2}$ KASSINDJA \& BASHIR, supra note 1 , at 233.

${ }^{3} I d$

${ }^{4} I d$. at 241 .

${ }^{5} I d$.

${ }^{6} I d$. at 643 . 
migrant should be kicked out of the country — removal — is a civil one. ${ }^{7}$ Migrants that are physically held by the government during the pendency of their removal hearings - such as Fauziya - are detained pursuant to civil, not criminal, law. ${ }^{8}$ This is unusual. The only non-immigration examples of physical detention under civil law in the United States are imprisonment as a sanction for civil contempt ${ }^{9}$ and involuntary commitment to a mental hospital. ${ }^{10}$ Debtors' prisons, once a leading example of civil confinement, were abolished by federal law in $1883 .{ }^{11}$

While it is unusual to physically detain persons through civil law means, the conditions under which migrants are held for their violations are familiar. Adult facilities look and feel exactly like the jails and prisons that hold criminal defendants and those convicted of crimes. Indeed, migrants are often civilly detained within existing jails and prisons alongside criminal justice detainees. ${ }^{12}$ Even special-purpose immigration detention facilities are often designed by entities who build criminal detention sites, and

\footnotetext{
${ }^{7}$ Mahler v. Eby, 264 U.S. 32, 39 (1924) ("It is well settled that deportation, while it may be burdensome and severe for the alien, is not a punishment.").

${ }^{8}$ See 8 U.S.C. $\S \S 1225(\mathrm{~b})(1)(B)(i i i)(I V), 1225(b)(2), 1226(a)$, and 1226(c).

${ }^{9}$ See Int'l Union v. Bagwell, 512 U.S. 821, 828 (1994) ("The paradigmatic coercive, civil contempt sanction . . . involves confining a contemnor indefinitely until he complies with an affirmative command such as an order 'to pay alimony, or to surrender property ordered to be turned over to a receiver, or to make a conveyance."'). Courts that impose an imprisonment or confinement sanction for civil contempt send the contemnor to jail. See, e.g., Gerald Lebovits, Drafting New York Civil-Litigation Documents: Part XXXVContempt Motions Continued, N.Y. State BAR J., Sept. 2014, at 59. One could also conceive of the civil subpoena power - forcing the production of testimony under oath — as another form of civil detention, albeit one that does not involve confinement in a jail or prison. See, e.g., Graham Hughes, Administrative Subpoenas and the Grand Jury: Converging Streams of Criminal and Civil Compulsory Process, 47 VAND. L. REV. 573, 594 (1994) (discussing, in particular, civil administrative subpoenas).

${ }^{10}$ See, e.g., United States v. Comstock, 560 U.S. 126 (2010) (dismissing a constitutional challenge to civil commitment).

${ }^{11}$ See Eli Hager, Debtors' Prisons, Then and Now: FAQ, Marshall Project (Feb. 24, 2015), https://www.themarshallproject.org/2015/02/24/debtors-prisons-then-and-now-faq [https://perma.cc/M27MF9D3] (noting debtor's prisons were banned under federal law in 1833).

12 See, e.g., Jennifer M. Chacón, Immigration Detention: No Turning Back?, 113 S. ATLANTic Q 621, 623 (2014) ("immigrant detainees are frequently housed in the same facilities as criminal offenders, and under the same conditions."); Dora Schriro, Immigration Detention Overview and Recommendations 2 (Oct. 6, 2009), https://www.ice.gov/doclib/about/offices/odpp/pdf/ice-detention-rpt.pdf [https://perma.cc/Z9JL-HN4P] ("With only a few exceptions, the facilities that ICE uses to detain aliens were built, and operate, as jails and prisons to confine pre-trial and sentenced felons.").
} 
their forms mimic those of traditional carceral settings. ${ }^{13}$ Common features include remote locations, secure perimeter fencing, locked doors, surveillance machinery, immobile furniture, and 24-hour lighting. ${ }^{14}$ Beyond their physical features, immigration detention centers are run in a parallel fashion to institutions of criminal incarceration. ${ }^{15}$ Most facilities have uniformed guards who enforce strict rules and count detainees several times a day. ${ }^{16}$ Detainees frequently wear uniforms, are separated by their assessed level of risk to others, have limited time outdoors, enjoy limited mobility inside the detention facility, have limits on their personal possessions (e.g., number and type of books), experience time constraints on everything from showers to meals, and are not entitled to contact visits with their families. ${ }^{17}$

A significant number of migrants are held in detention. In 2019, the United States maintained a daily average immigration detention population in excess of 50,000, with more than 500,000 individual migrants detained that year. ${ }^{18}$ Females make up a

\footnotetext{
${ }^{13}$ The Otay Mesa Detention Center outside of San Diego is one example. It was built in the 1990s by CCACorrections Corporation of America, now rebranded as CoreCivic - to be the area's first immigration detention center. See Maya Srikrishnan, What We Know About the Otay Mesa Detention Center - and Its Future, VOICE OF SAN DIEGO (Oct. 7, 2019), https://www.voiceofsandiego.org/topics/government/what-weknow-about-the-otay-mesa-detention-center-and-its-future/ [https://perma.cc/NB8F-M6B3]. CCA was founded in 1983, "pioneer[ing] the idea of running prisons for a profit." See Madison Pauly, A Brief History of America's Private Prison Industry, MOTHER JONES (July/Aug. 2016), https://www.motherjones.com/politics/2016/06/history-of-americas-private-prison-industry-timeline/ [https://perma.cc/NZM6-8KF7].
}

${ }^{14}$ See, e.g., César Cuauhtémoc García Hernández, Immigration Detention as Punishment, 61 UCLA L. ReV. $1346,1349,1383-89$ (2014).

${ }^{15} \mathrm{Id}$.

${ }^{16} \mathrm{Id}$.

${ }^{17} I d$. The carceral conditions under which migrants are detained are "systematically and unnecessarily ... inappropriate for immigration's noncriminal purposes." Anil Kalhan, Rethinking Immigration Detention, 110 Colum. L. Rev. Sidebar 42, 43 (2010); see also Schriro, supra note 12, at 2-3 (noting that carceral norms "impose more restrictions and carry more costs than are necessary to effectively manage the majority of the detained population."). Facilities for unaccompanied migrant children are somewhat different, though, like adults, many are housed in locked facilities and subject to continuous supervision. See Linda Kelly Hill, The Right to Know Your Rights: Conflict of Interest and Assistance of Unaccompanied Alien Children, 14 U.C. DAVIS J. Juv. L \& POL’Y 263, $277-78$ (2010).

\footnotetext{
${ }^{18}$ U.S. IMMigRATION AND CUSTOMS ENFORCEMENT FisCAL YeAR 2019 ENFORCEMENT AND REMOVAL OPERATIONS REPORT, https://www.ice.gov/sites/default/files/documents/Document/2019/eroReportFY2019.pdf [https://perma.cc/MA8N-YEK2].
} 
substantial portion of the detainee population. In 2019, an average of 7,700 noncitizen women were held in immigration detention facilities daily and another 4,500 migrant women were held in local jails awaiting transfer to immigration detention. ${ }^{19}$ Most of these women menstruate. ${ }^{20}$

Conditions for menstruating women in immigration custody today are not substantially different from those experienced by Fauziya Kassingja in 1994. A 2019 investigation by the state of Washington found that menstruating teens in immigration custody were given a single pad a day, ${ }^{21}$ with no opportunity to shower or to get a change

\begin{abstract}
${ }^{19}$ Aleks Kajstura, Women's Mass Incarceration: The Whole Pie 2019, Prison Policy InITIATIVE (Oct. 29, 2019), https://www.prisonpolicy.org/reports/pie2019women.html [https://perma.cc/5R57-8DWH]. See also Immigration and Customs Enforcement Detention, TRAC IMMIGR. (JULY 2019), https://trac.syr.edu/phptools/immigration/detention/ [https://perma.cc/H6NL-QYXZ] (noting 9,176 of the 55,654 migrants in ICE custody in July 2019 were female).
\end{abstract}

${ }^{20}$ See Profile of the Unauthorized Population: United States, Migration Policy Institute (2018), https://www.migrationpolicy.org/data/unauthorized-immigrant-population/state/US [https://perma.cc/LHM9YT8L] (seventy-three percent of the undocumented population are under the age of forty-four; eighty-eight percent are under the age of fifty-four). Other data indicates the median age of deportees is 30. ICE Deportations: Gender, Age, and Country of Citizenship, TRAC IMMIGR., (April 9, 2014), https://trac.syr.edu/immigration/reports/350/ [https://perma.cc/FA8E-EVL5]. Further age-related data is difficult to come by; the Transactional Records Access Clearinghouse (TRAC), which collects information regarding immigration detention, and other topics, utilizing Freedom of Information Act, reports that ICE has withheld records providing more data on age. See Transactional Records Access Clearinghouse, TRAC IMMIGR., https://trac.syr.edu/aboutTRACgeneral.html [https://perma.cc/CRM6-L9KA] (explaining TRAC's mission); About the Data - ICE Detention, TRAC IMMIGR.,

https://trac.syr.edu/phptools/immigration/detention/about_data.html [https://perma.cc/GBD2-FHLG] (reporting that ICE has been withholding data regarding the age of detainees). It should be noted that transgender men in immigration custody may also menstruate. See, e.g., Chloe Atkins, For Transgender Men, Pain of Menstruation is More Than Just Physical, NBC NEws (Jan. 11, 2020),

$\mathrm{https} / / / \mathrm{www} . n b c n e w s . c o m /$ feature/nbc-out/transgender-men-pain-menstruation-more-just-physical-n1113961 [https://perma.cc/FFU3-TX7X] (discussing hurdles facing trans men who menstruate). By at least one account, the numbers of trans men in immigration custody are low. See Silvia Foster-Frau, Detention Unit in South Texas Holds Transgender Immigrants, NBCDFW (June 7, 2019),

https://www.nbcdfw.com/news/local/detention-unit-in-south-texas-holds-transgender-immigrants/247623/ [https://perma.cc/JP9K-864N] (noting that while ICE held nearly 300 transgender detainees in first eight months of FY2019, "only a handful" were trans men). No matter how few or many, trans men who menstruate deserve accommodations for menstruation as well as women and girls.

${ }^{21}$ A single soaked pad or regular-sized tampon will hold $5 \mathrm{ml}$ of blood. See Jerilynn C. Prior, Very Heavy Menstrual Flow, Centre for Menstrual Cycle and Ovulation Research (Oct. 4, 2017),

https://www.cemcor.ubc.ca/resources/very-heavy-menstrual-flow [https://perma.cc/2JVX-RG7B]. Menstrual cycles vary among women both in length and flow. One study found a median cycle of five days. See Sonya S. Dasharathy et al., Menstrual Bleeding Patterns Among Regularly Menstruating Women, 175 Aм. J. EPIDEMIOLOGY 536, 539 (2012). The authors characterized cycle flows as light if blood flow was less than or 
of clothing after visibly bleeding through their clothes. ${ }^{22}$ A 2009 Human Rights Watch report found that menstruating adult women in immigration custody face similar challenges: officials distributed only a set number of sanitary pads, women experienced difficulties obtaining more pads as needed, and women were forced to wear soiled clothing when their sanitary supplies proved inadequate for their flow. ${ }^{23}$ That same report found women also suffered from poor medical care associated with menstruation. One detainee suffered from ovary inflammation for which her doctor had prescribed birth control pills, but she was not permitted to continue this medication during her immigration detention. ${ }^{24}$ Other detainees interviewed had difficulty obtaining medical treatment for gynecological concerns even when faced with extreme pain, heavy clots, ${ }^{25}$ and abnormal menstruation cycles. ${ }^{26}$

equal to $36.5 \mathrm{ml}$, medium if flow was between $36.5 \mathrm{ml}$ and $72.5 \mathrm{ml}$, and heavy if flow exceeded $72.5 \mathrm{ml}$, noting flow was routinely heavier in the first three days of any cycle. Id. at 537. Thus, looking at flow capacity alone, a menstruating girl or woman would need two pads or regular-sized tampons per period day if experiencing light flow (as $36.5 \mathrm{ml} \div 5$ days $=7.3 \mathrm{ml} /$ day) or more than four if experiencing heavy flow (as $72.5 \mathrm{ml} \div 5$ days $=14.5 \mathrm{ml} /$ day). See also Dasharthy, supra note 21 (noting flow is highly variable and in one study a woman lost $540 \mathrm{ml}$ of blood, which would necessitate significantly more sanitary products). But flow capacity is not the only concern for menstruating women and girls. Those who use tampons for more than six hours or overnight are at greater risk for toxic shock syndrome, a life-threatening bacterial infection. See Amaury Billion et al., Association of Characteristics of Tampon Use with Menstrual Toxic Shock Syndrome in France, 21 LANCET 100308 (2020). Thus, to avoid the risk of toxic shock syndrome, menstruating women need a minimum of four pads or tampons per day.

${ }^{22}$ Affidavit of Alma Poletti, Investigation Supervisor for the Washington State Attorney General's Office (AGO), Civil Rights Division, ๆๆ 19, 36, August 23, 2019, https://agportal-

s3bucket.s3.amazonaws.com/uploadedfiles/Another/News/Press_Releases/2019-08-

23\%20Poletti_Declaration_FloresCDCA_Washington_FINAL.pdf [https://perma.cc/GSB7-47RV].

${ }^{23}$ Detained and Dismissed: Women's Struggles to Obtain Health Care in United States Immigration Detention, Human Rights Watch (Mar. 17, 2009), https://www.hrw.org/report/2009/03/17/detained-anddismissed/womens-struggles-obtain-health-care-united-states [https://perma.cc/R28R-4T5M] (discussing lack of period products and bleeding through clothing).

${ }^{24} I d$. (story of “Serafina D.").

${ }^{25}$ Menstrual clots, made up of "a mixture of blood cells, tissue from the lining of the uterus, and proteins in the blood," commonly appear in menstrual blood. See Jon Johnson, Are Blood Clots Normal during a

Period?, Med. News Today (Nov. 15, 2018), https://www.medicalnewstoday.com/articles/322707

[https://perma.cc/7KVH-A6UN]. Some clotting - if larger than a quarter, frequent, appearing with abnormally heavy flow, or accompanying pain - can be a symptom of a more serious medical problem. Id. See also Prior, supra note 21 (noting the passage of large clots can be linked to menorrhagia, the medical term for very heavy flow).

${ }^{26}$ HuMAN RighTS WATCH, supra note 23 (story of "Nadine I."). 
The simple and obvious solution to these unacceptable conditions is for menstruating women in immigration detention to have unlimited access to period products and adequate gynecological care. ${ }^{27}$ The problem is that they are already supposed to have that. The national standards currently applicable to immigration detention require that "female detainees shall be issued and may retain sufficient feminine hygiene items, including sanitary pads or tampons[.] ${ }^{\prime 28}$ The standards also require detention facilities to "replenish personal hygiene items at no cost[.]"29 Furthermore, all immigration detainees

${ }^{27}$ Other readers might argue that the simple and obvious solution is the abolition of immigration detention. See, e.g., César Cuauhtémoc García Hernández, Abolishing Immigration Prisons, 97 B.U. L. REv. 245 (2017).

${ }^{28}$ U.S. Immigr. And Customs Enforcement, National Detention Standards For Non-Dedicated FACILITIES 128 (2019), https://www.ice.gov/doclib/detention-standards/2019/nds2019.pdf [https://perma.cc/LG9Q-HGRX] (Standard 4.4 § II.F) (hereinafter ICE NDS); see also U.S. IMMIGR. AND Customs Enforcement, Performance-Based National Detention Standards 2011101 (2011) (Standard 2.6.V.B.2), https://www.ice.gov/doclib/detention-standards/2011/pbnds2011r2016.pdf [https://perma.cc/P3TA-WJQT] (noting unprocessed detainees "shall be provided with basic hygiene items" including "feminine-hygiene items") (hereinafter ICE PBNDS); id. at 329 (Standard 4.5.V.D) ("Female detainees shall be issued and may retain sufficient feminine hygiene items, including sanitary pads or tampons, for use during the menstrual cycle"). Apropos of the earlier discussion regarding the carceral features of civil immigration detention - see supra notes 12-17 and accompanying text — both sets of immigration detention standards developed out of the American Correctional Association standards for pretrial felons. See Anita Sinha, Slavery by Another Name: "Voluntary" Immigrant Detainee Labor and the Thirteenth Amendment, 11 StAn. J. Civ. RTS. \& Civ. LiberTies 1, 20 (2015).

${ }^{29}$ ICE NDS, supra note 28, at 128 (Standard 4.4 § II.F); see also ICE PBNDS, supra note 28, at 329 (Standard 4.5.V.D) ("The responsible housing unit officer shall replenish personal hygiene items on an asneeded basis"). The existence of national standards regarding immigration detention means that menstruating migrants should, theoretically, have easier access to period products than criminal defendants in jails and prison inmates. That's because the vast majority of individuals in jails and prisons are subject to state, not federal law. See Kajstura, supra note 19 (noting local jails housed 101,000 women and state prisons another 99,000 women, whereas far fewer women were held in federal custody: 16,000 in federal prisons and jails along with 7,700 in immigration detention). State law regarding access to period products varies. See Mitchell O'Shea Carney, Note, Cycles of Punishment: The Constitutionality of Restricting Access to Menstrual Health Products in Prisons, 61 B.C. L. REv. 2541, 2543 (2020) ("Thirty-eight states currently do not have any legislation requiring prisons to provide adequate supplies of pads or tampons, and instead leave the distribution of menstrual health products to individual prison officials."). In Indiana, for example, a state congresswoman recently introduced a bill to require the state's department of corrections to provide "free and unlimited access to ... tampons ... and menstrual pads to any incarcerated woman held by the department." See House Bill No. 1349 http://iga.in.gov/static-documents/8/3/9/1/839124ba/HB1349.01.INTR.pdf [https://perma.cc/BGC6-BCJR] (introduced in January 2021). Indiana law does not currently provide for unlimited access to free period products in state-run prisons. Federal prisoners, in contrast, are statutorily entitled to free tampons and sanitary napkins. See First Step Act of 2018, Pub. L. No. 115-391 § 611, 132 Stat. 5194, 5274. 
"shall have access to appropriate medical . . care," ${ }^{30}$ with women specifically entitled to "age appropriate gynecological and obstetrical health care[.]",31

It is, therefore, a question of enforcement: making sure that the line officers in charge of distributing sanitary products and the medical personnel in charge of evaluating gynecological concerns actually provide the goods and services they are required to under the federal standards. ${ }^{32}$ There are myriad ways in which this could happen. Women's bathrooms could be stocked with freely available tampons and pads. If officers insist on maintaining control over these items, signs could be placed near where they are stored, noting "all sanitary supplies are freely available upon request." Detention officers could be subject to mandatory education on the topic of menstruation and the requirement to

\footnotetext{
${ }^{30}$ ICE NDS, supra note 28, at 112 (Standard $4.3 \S$ I).

${ }^{31}$ Id. at 124 (Standard 4.3§ II.U); see also ICE PBNDS, supra note 28, at 322 ("Female detainees shall receive routine, age appropriate gynecological and obstetrical health care, consistent with recognized community guidelines for women's health services.”).
}

${ }^{32}$ Maunica Sthanki has characterized the immigration detention standards as "nonbinding, nonregulatory, and unenforceable." Maunica Sthanki, Deconstruction Detention: Structural Impunity and The Need for an Intervention, 65 Rutgers L. REv. 447, 464 (2013); see also César Cuauhtémoc García Hernández, Due Process and Immigrant Detainee Prison Transfers, 21 Berkeley La RAZA L.J. 17, 54 (2011) (noting detention standards are not "legally enforceable" and concluding "[c]ompliance with these standards, therefore, results only from the government's good graces."); Roya Butler et al., Correctional Facilities, 20 GEORGETOWN J. GENDER \& L. 357, 389-90 (2019) (noting that detention standards "are supposed to be contractually binding on DHS facilities, but these standards lack enforcement mechanisms, and facilities that do not meet the standards are not held accountable.”); Emily Ryo \& Ian Peacock, A National Study of Immigration Detention in the United States, 92 S. CAL. L. REv. 1 (2018) ("None of these standards are legally enforceable regulations. As the U.S. Commission on Civil Rights has concluded, the nonbinding nature of these standards often means that the "facilities are not held accountable when they fail to maintain or meet these standards--at times with tragic results."') (footnote omitted). Sthanki rightly bemoans the lack of private rights of remedy to enforce existing detention standards through civil litigation as well as Supreme Court decisions that have limited the ability of detainees to sue the private-prison companies in charge of much of immigration detention. $I d$. at 450,472 . Detainees are entitled to file grievances based on detention standards failures, but many do not file out of fear of retribution and even those who do often fail to remedy their problem. Id. at 466-67. One way to give the standards bite would be, as Sthanki suggests, to strengthen accountability mechanisms (particularly criminal investigations and prosecution of detention abuses) combined with significant external oversight of detention practices (by, for example, the Department of Justice). Id. at 490, 496-97, 499-500. Another approach would be to give detainees a private right of action to enforce detention standards in federal court. See Stacey A. Tovino, Of Mice and Men: On the Seclusion of Immigration Detainees and Hospital Patients, 100 MinN. L. REV. 2381, 2426 (2016) ("DHS must make these standards legally enforceable."). A third alternative would be to codify the detention standards in federal regulations. See Stacey A. Tovino, The Grapes of Wrath: On the Health of Immigration Detainees, 57 B.C. L. Rev. 167, 169 (2016) (calling for the replacement of the health care detention guidelines with "rigorous federal regulations"). 
distribute sanitary products. Medical providers could be subject to similar educational requirements, emphasizing the importance of gynecological care.

Another solution to menstruation in immigration detention comes not from enforcing rights already owed, but from developments in the everyday management of menstruation. Several companies now sell high-quality and reusable period underwear. ${ }^{33}$ While period underwear cannot entirely replace traditional pads and tampons, it can provide coverage for light period days as well as a second layer of coverage for heavier period days and overnight protection. ${ }^{34}$ Federal agencies should consider purchasing period underwear ${ }^{35}$ and distributing it to menstruating females in custody, in addition to improving access to tampons and pads.

Females menstruate. This does not change when they enter custodial settings. It is up to the federal government to ensure that migrant women and girls within their charge consistently receive the period supplies and related medical care they need. The fact that the government has not consistently met this obligation highlights the problematic way in which civil immigration detention, ostensibly designed not to punish, ${ }^{36}$ nevertheless impermissibly punishes female migrants. ${ }^{37}$

\footnotetext{
${ }^{33}$ Such companies include, among others, Bambody, Knix, Modibodi, Proof, Ruby Love, and Thinx.

${ }^{34}$ Overnight protection is especially important for tampon users who are at greater risk for toxic shock syndrome if using tampons overnight. See Billion et al., supra note 21, at 5.

${ }^{35}$ This should not be a hard sell: The cost of period underwear would almost certainly be vastly outweighed by the savings incurred from avoiding the ruination of uniforms and bedding due to inadequate period coverage.

${ }^{36}$ See Zadvydas v. Davis, 533 U.S. 678, 721 (2001) (Kennedy, J., dissenting) ("Where detention is incident to removal, the detention cannot be justified as punishment nor can the confinement or its conditions be designed in order to punish.").

${ }^{37}$ See generally García Hernández, supra note 14 (arguing that immigration detention, while facially grounded in civil law, is actually punishment and, therefore, should be subject to the constitutional and statutory limitations that apply to criminal imprisonment); see also Kalhan, supra note 17, at 43 (arguing that "excessive immigration detention practices have evolved into a quasi-punitive system of immcarceration.").
} 